\title{
100. Yıl Dönümünde Maraş Savunması Bağlamında Ders Kitaplarında "Biz" ve "Onlar" 1
}

\author{
İrfan Davut ÇAM \\ Arş. Gör. Dr., Ondokuz Mayıs Üniversitesi, Eğitim Fakültesi \\ irfan.cam@omu.edu.tr \\ Orcid ID: https://orcid.org/0000-0002-0232-6376 \\ Murat Bayram YILAR \\ Dr. Öğr. Üyesi, Ondokuz Mayıs Üniversitesi, Eğitim Fakültesi \\ bayram.yilar@omu.edu.tr \\ Orcid ID: https://orcid.org/0000-0001-5889-3372
}

\begin{abstract}
Öz
$\mathrm{Bu}$ çalışmanın amacı, Millî Mücadele sürecinde cereyan eden Maraş Savunması'na dair günümüz ders kitaplarında yer bulan satırları temel alarak "biz" ve "onlar"a ilişkin açıklamaları analiz etmektir. Bu amaç doğrultusunda çalışma, nitel bir araştırma olarak tasarlanmıştır. Çalışmanın veri kaynaklarını günümüzde farklı kademelerde okutulan Sosyal Bilgiler ve Türkiye Cumhuriyeti İnkılâp Tarihi ve Atatürkçülük ders kitapları oluşturmuş̧ur. Bu ders kitaplarından, 1 adet 4 . sinif Sosyal Bilgiler, 2 adet 8 . sinif ve 1 adet 12. sinif Türkiye Cumhuriyeti İnk1lâp Tarihi ve Atatürkçülük olmak üzere toplam 4 adet seçilmiştir. Kitaplar seçilirken, anılan konuyu içermiş olmalarına ve Millî Eğitim Bakanlığı Talim ve Terbiye Kurulu Başkanlığı'nın onayından geçmiş olmalarına dikkat edilmiştir. Söz konusu ders kitaplarından çalışmanın konusuna ilişkin verilerin toplanması amacıyla doküman analizi yöntemine başvurulmuştur. $\mathrm{Bu}$ yöntemle toplanan veriler, içerik analizi tekniğiyle çözümlenmiştir. Yapılan analiz sonucunda, Maraş Savunması bağlamında ders kitaplarında "biz"e ve "onlar"a dair önemli ve dikkat çekici noktalar tespit edilmiştir.
\end{abstract}

Anahtar Kelimeler: Ders Kitapları, Maraş Savunması, "Biz" ve "Onlar".

\footnotetext{
${ }^{1}$ Makale Geliş/Kabul Tarihi: 15.12.2019 / 29.01.2020

Künye Bilgisi: Çam, İ. D. ve Yllar, M. B. (2020). 100. Yll Dönümünde Maraş Savunması Bağlaminda Ders Kitaplarında "Biz" ve "Onlar". Kahramanmaraş Sütçü Imam Üniversitesi Sosyal Bilimler Dergisi, 17 (Özel Sayl), 43-58. DOI: 10.33437/ksusbd.659765
} 


\title{
"We" And "They" In The Textbooks Within The Context Of The Marash Defence At Its Centenary
}

\begin{abstract}
The aim of this study is to analyse the explanations with regard to "we" and "they" based upon the narrative of the Marash Defence which is found in the today's textbooks. The study was designed as a qualitative research to this end. The data sources of the study consist of Social Studies and the Republic of Turkey Revolution History and Kemalism textbooks taught in the different grade today. In this scope, 4 of these textbooks were chosen in total. 1 of them is Social Studies textbook taught in fourth-grade and 3 of them are the Republic of Turkey Revolution History and Kemalism textbooks. It should be emphasized that students read the last textbooks at the eighth and twelfth grades. In the selection of these textbooks, it was taken into consideration that they included the subject above-mentioned and that they were approved by the Head Council of Education and Morality of the Ministry of National Education. Document analysis method was employed to collect data related to the subject of the study from the textbooks in question. Collected data were analysed with the content analysis technique. In result of the analysis, important and remarkable points were identified about "we" and "they" within the context of the Marash Defence in the textbooks.
\end{abstract}

Keywords: Textbooks, Marash Defence, "We" and "They".

\section{GíRiș}

Sosyal bilimlerde farklı şekillerde tanımlanan ideolojinin, toplumsal bir gruba mensup bireyler arasında birlik, beraberlik, kaynaşma ve dayanışma sağlama ve bu bağlamda bir kimlik oluşturma işlevi bulunmaktadır (Gutek, 2014: 178). İdeolojinin bu işlevi, okullarda özellikle de onları etkili birer ideolojik aygıt haline dönüştüren pek çok unsurun katkısıyla hayat bulmaktadır. Bu unsurların başında hiç şüphesiz ders kitapları gelmektedir.

Ders kitapları, bir ülkedeki meşru bilginin sınırlarını belirleyen, bu bilgiyi aktaran ve her defasında yeniden üreten temel eğitim araçlarından biridir. $\mathrm{Bu}$ kitaplar bizzat kapakları, ihtiva ettikleri görseller, kullandıkları dil, ele aldıkları yahut almadıkları konularla muhatapları için birtakım mesajlarla yüklüdürler. $\mathrm{Bu}$ mesajlar yoluyla ders kitapları, bir ülkedeki egemen ve normal söylemin kodlarını gösteren, hangi konular hakkında konuşulabileceğini ve hangi konuların birer tabudan ibaret olduğunu saptayan kaynaklardır. Daha da önemlisi bir toplumsal grubun resmî öyküsünün anlatıldığı temel kaynaklardan biri olan 


\section{I.D. Cam ve M.B. Yılar $\quad$ 100. Yıl Dönümünde Maraș Savunması...}

ders kitapları, o toplumsal grubun kim olduğuna, kimlerden oluştuğuna, nasıl bir geçmişe sahip olduğuna, hali hazırda içinde bulunduğu konuma ve nihai olarak gelecek vizyonuna dair bir anlatı sunarlar. Bir diğer ifadeyle ders kitaplarında devlet ve toplum tarihsel bir bağlama oturtulur ve bu bağlamda ortak bir aidiyet bilinci; yani "biz" bilinci inşa edilir (Çayır, 2014: 1, 9).

"Biz" bilincinin inşa edilmesindeki amaç aynı düşünen, benzer değerlere sahip, müşterek tutum ve davranışlar geliştiren bireyler yaratmaktır. Söz konusu düşünce, değer, tutum ve davranışların ortaya konulması ise egemen söylemin çizdiği sınırlar içerisinde varlığ 1 idame ettirmeye dönüktür. Zira ancak "biz" kapsamına girmeyi kabul edenler, belirlenmiş olan bu sınırlar içerisinde kalabilirler ve egemen güç tarafindan cömertçe ödüllendirilirler. Aksi takdirde "öteki"leşilecek ve dolayısıyla pek çok haktan mahrumiyetle yüzleşmek durumunda kalınacaktır. Bu çerçevede ideoloji, "biz"i sunmanın bir biçimi olduğu kadar, onu anlamlı k1lan "onlar"1; yani "öteki"yi de sunmanın bir biçimidir (Parlak, 2005: 84; Van Dijk, 2015: 28).

Bu anlamda, kimlik inşasında "biz" önemlidir; fakat tek başına yeterli değildir. "Onlar"ın kim oldukları, kimlerden oluştukları yahut ne oldukları meselesi de açıklığa kavuşturulmalıdır. Zira "biz"in olduğu, fakat "onlar"ın olmadığı bir toplumda kimlikten, toplumsal gruplardan bahsetmek mümkün değildir (Tekeli, 2015: 2). Ait olunan grubu temsil eden "biz", genellikle olumlanan yahut yüceltilendir. "Biz"im olan her şey önemli ve değerli görülür. Burada grup kimliğini yüceltici anılar ön plana çıkarılır. Olumsuz olaylar ise gündeme taşınmaz yahut göz ardı edilirler. Ya da geçmiş yaşantılar, mensubu olunan grubu meşrulaştıracak bir şekilde yeniden üretilirler. "Biz"e anlam kazandıran "onlar"ın karşıllğı ise duruma göre bir sınıf, cinsiyet ya da kültürel, etnik, dinsel gruplar olabilmektedir. "Biz" ve "onlar" arasında kaçınılmaz bir karşılıklı ilişki söz konusudur (Bilgin, 2013: 76; Pingel, 2004: 25).

Genellikle ait olmak istenilmeyen, önemsiz olan, aşağılanan, küçümsenen ya da yok sayılan "onlar", "biz" ile ancak birlikte, karşılıklı çatışma içinde anlaşılabilirler. Ait olduğumuz grubun öz kimliği, tutarlılığı, kendi içindeki dayanışması ve duygusal güvenliği, ait olmadığımız grubun varlığına bağlıdır. Böyle bir grup yoksa bile kendi sınırlarını çizmek ve korumak, kendi içinde sadakat ve işbirliğini temin etmek, grubun tutarl1llğ 1 , bütünlüğü ve üstünlügü̈ adına icat edilebilir (Bauman, 2010: 51-53; Güvenç, 1995: 7). Sadece iki ayrı insan grubunu değil, aynı zamanda bütünüyle farklı iki tutum, duygusal bağlanma ve antipati (iticilik-soğukluk), güven ve şüphe, güvenlik ve korku, işbirliği ve çekişme arasındaki ayrımı da temsil eden (Bauman, 2010: 51) "biz" ve "onlar" ayrımı, ön yargılarla da ilintili bir durumdur. Öğrenilen bir davranış olan ön yargı, öncelikle aile ortamında kazanılmaktadır. Yapılan araştırmaların da gösterdiği üzere, çocuklar ön yargılarının önemli bir kısmını daha okul sıralarıyla 
buluşmadan aile ortamında edinmektedirler. Bununla birlikte, çocukluğun çözüme kavuşturulmamış çatışmalarına bağlı olduğundan kişiliğin oluşumunu derinden etkileyen ön yargıların grup düzeyinde gelişmeleri ise grup stereotiplerinin (kalıpyargı) yaratılmasıyla yakından ilintilidir (Schnapper, 2005: 132; Tekeli, 2015: 3-4). Stereotipleştirme bütün bir yaş grubunu, cinsiyeti, ırk1 ya da dini karakterize eden veya betimleyen bir kişiye yahut gruba karşı tavır takınmak olarak tanımlanabilir. Stereotipler, genellikle bir kişiye ya da bütün bir kültüre ilişkin olumlu ya da olumsuz bir değerlendirme ile sonuçlanan yaygın bilişsel bir şema üretirler (Manning \& Baruth, 2004: 22). Çeşitli gruplara ilişkin ön yargıya dayalı stereotipler, sadece bilişsel şemalardan ibaret değildirler. Bunlar aynı zamanda toplumsal temsil araçlarıdırlar. Diğer bir deyişle toplumdaki gruplar hakkında nesnelleştirilmiş bilişsel ve hissi yapılardır. Belli bir tarihsel andaki toplumsal ve siyasî ortamda doğup yaygınlaşırlar. Ön yargılarla kurulmuş stereotipler, grupların birbirlerine yakıştırdıkları sıfatlar toplumdaki egemen gruplar arası ilişkiler örüntüsünün meşrulaştırılmasına ve sürdürülmesine imkân tanıyan ideolojik unsurlardır. Bu ideolojik unsurların "biz"i yücelten, "onlar"1 kötüleyen, aşağılayan, dışlayan imgeleri ihtiva ettikleri söylenebilir (Dragonas, 2015: 119,123). Düşman imgesi, bu anlamda önemlidir. Bireyin mensubu olduğu grubun renkleri kendisi için hiç şüphesiz huzur verici ve iç açıcıdır. Grubuyla özdeşleşmek ona güvenlik ve gurur duygusu verir. Oysa düşman imgesi insanın ruhunu ürperten, ona sıkıntılar veren donuk ve korkutucu renklerle boyanmıştır. Bu konuda ciddi bir önem atfedilen ders kitaplarında düşman ve eylemleri öyle bir yorumlanarak sunulur ki, her yapıp ettikleri imgelerini daha fazla karartır. "Ne yaparsan yap, ne söylersen söyle, yerden yere vurulacak ve sana karşı kanıt olarak kullanılacaktır" kaidesine uygun olarak yapılanlarda "kötücül" dürtüler bulunur. Düşmanın her hamlesi, "hain" emellerinin gün yüzüne çıkarılması için büyüteç altına alınır (Bauman, 2010: 5758; Schnapper, 2005: 151) ve çocuklara/gençlere düşmanlarını daha yakından tanımalarını sağlayacak bir formatta takdim edilir. Amaç, tüm farklılıkları bir kenara bırakarak grubun küçük üyelerini ve dolayısıyla geleceğin büyüklerini vazedilen tehdit unsuruna ya da "düşman öteki"ye karşı bilinçli kılmak, onlara sadakat duygusu aşılamak, kendilerini bir araya getirerek kaynaştırmak ve yekvücut k1lmaktır.

Wilhelm Schmid'in de (2017: 16-18) işaret ettiği üzere düşman ve dolayısıyla düşmanlık, "biz" bilincinin tahkîminde önemli bir rol üstlenmektedir. Her şeyden önce hayatta dayanak ve yönelim sağlayan düşmanlık, olumsuz bir değer olmakla birlikte temel bir izlek gibi hayatın evrelerini kat ederek devamlılığın teminatı olmaktadır. Düşmanlık, ait olunan grubun üyeleri arasındaki sevginin ve dayanışma bağlarının güçlenmesinde, bunların her defasında değerlileşmesinde, söz konusu üyelerin zayıf yönlerinin keşfedilip giderilmesinde ve kendilerinin belli bir hedefe doğru motive edilmelerinde önemli bir belirleyicidir. Grup üyelerinin "bir arada olursak onlarla, bizi (ve) bizim kendine özgülüğümüzü 


\section{İ.D. Cam ve M.B. Yılar $\quad$ 100. Yıl Dönümünde Maraș Savunması...}

tehdit edenlerle baş edebiliriz!" duygusunu kazanması bir şekilde düşmanın varlığıyla anlam kazanmaktadır. Bu bağlamda, düşman/düşmanlık onlara "ne olmadıklarını"; tersine çevirerek söylemek gerekirse "kim olduklarını" öğretmektedir.

"Biz" ve "onlar" arasındaki bu ayrım, geçmiş ders kitaplarında olduğu gibi önemli farklılıklarla birlikte günümüz ders kitaplarında da yerini korumuştur. $\mathrm{Bu}$ durumu, Millî Mücadele yıllarında cereyan eden ve günümüz ders kitaplarında önemle yer bulan Maraş Savunması'na ilişsin anlatıda rahatlıkla tespit etmek mümkündür. Nitekim bu çalışmada, Maraş Savunması'na dair günümüze ait ders kitaplarında yer alan satırlar temel alınarak "biz"e ve "onlar"a ilişkin açıklamaların analizi amaçlanmıştır. Maraş Savunması gibi Millî Mücadele tarihinde altın harflerle kayıt altına alınması gereken gelişmelerin yeni nesillerde millî bir bilinç inşa etmek, kendilerine birlik ve beraberlik ruhu aşılamak adına önemli olduğu unutulmamalıdır. Yapılan incelemeler sonucunda bu önemli savunmanın ve sonuçlarının bugüne değin pek çok çalışmada farklı boyutlarıyla ayrıntılı bir şekilde ele alındığı (Akbıyık, 1999; Çabuk, 2018; Eyicil, 2005; Gönen, 2005; Kerr, 1973; Şavkıll, 2017; Ünalp, 2018; Yakar, 2018; Yetişgin, 2004) ancak ders kitaplarındaki yerinin yeterince irdelenmediği saptanmıştır. Bu çalışmayla Maraş'ın millî mücadelesi olarak tarif edilebilecek olan bu önemli gelişmeye "biz" ve "onlar" temelinde odaklanılarak yeni araştırmalara küçük de olsa bir pencere açılmaya çalışılmıştır.

\section{MATERYAL VE YÖNTEM}

Nitel bir araştırma olarak tasarlanan bu çalışmada, 2018-2019 eğitim-öğretim yılından itibaren üç farklı kademede okutulmak üzere hazırlanmış olan Sosyal Bilgiler ve Türkiye Cumhuriyeti İnkılâp Tarihi ve Atatürkçülük ders kitapları veri kaynağ 1 olarak kullanılmıştır. Bu ders kitaplarından, Tablo 1'de de görüldüğü üzere, 1'i 4. sınıf Sosyal Bilgiler, 2'si 8. sınıf ve 1'i de 12. sinıf Türkiye Cumhuriyeti İnkılâp Tarihi ve Atatürkçülük olmak üzere toplam 4 adet seçilmiştir. Bu kitaplar seçilirken, anılan konuyu içermiş olmalarına ve Millî Eğitim Bakanlığı Talim ve Terbiye Kurulu Başkanlığı'nın onayından geçmiş olmalarına dikkat edilmiştir.

Tablo 1. Araştırmada Veri Kaynağı Olarak Başvurulan Ders Kitapları

\begin{tabular}{|l|l|l|l|}
\hline \multicolumn{1}{|c|}{ Yazar } & \multicolumn{1}{|c|}{ Kitap } & Yıl & \multicolumn{1}{c|}{ Yayınevi/yeri } \\
\hline $\begin{array}{l}\text { Sami } \\
\text { Tüysüz }\end{array}$ & $\begin{array}{l}\text { İlkokul Sosyal Bilgiler- } \\
\text { 4. Sınıf }\end{array}$ & 2018 & $\begin{array}{l}\text { Tuna Matbaacılık } \\
\text { A.Ş./Ankara }\end{array}$ \\
\hline
\end{tabular}




\begin{tabular}{|c|c|c|c|}
\hline $\begin{array}{l}\text { Çiğdem } \\
\text { Ataş \& } \\
\text { Ufuk Ataş }\end{array}$ & $\begin{array}{l}\text { Türkiye Cumhuriyeti } \\
\text { İnkılâp Tarihi ve } \\
\text { Atatürkçülük-8. Sınıf }\end{array}$ & 2018 & $\begin{array}{l}\text { Top Yayıncılık / } \\
\text { İzmir }\end{array}$ \\
\hline $\begin{array}{l}\text { Sinan } \\
\text { Baydar \& } \\
\text { Ferhat } \\
\text { Öztürk }\end{array}$ & $\begin{array}{l}\text { Türkiye Cumhuriyeti } \\
\text { İnk1lâp Tarihi ve } \\
\text { Atatürkçülük-8. Sınıf }\end{array}$ & 2018 & $\begin{array}{l}\text { MEB Yayınları / } \\
\text { Ankara }\end{array}$ \\
\hline $\begin{array}{l}\text { Akif } \\
\text { Çevik, Gül } \\
\text { Koç \& } \\
\text { Koray } \\
\text { Şerbetçi }\end{array}$ & $\begin{array}{l}\text { Türkiye Cumhuriyeti } \\
\text { İnk1lâp Tarihi ve } \\
\text { Atatürkçülük-12.Sınıf }\end{array}$ & 2018 & $\begin{array}{l}\text { MEB Yayınları / } \\
\text { Ankara }\end{array}$ \\
\hline
\end{tabular}

$\mathrm{Bu}$ ders kitaplarından çalışmanın konusuna ilişkin verilerin toplanması amaciyla doküman analizi yöntemine başvurulmuştur. Doküman analizi, basılı ve elektronik dokümanların incelenmesine veya değerlendirilmesine yönelik sistematik bir yöntemdir. Nitel araştırmalardaki diğer analitik yöntemler gibi doküman analizi de anlamı ortaya çıkarmak, anlamak ve nihai olarak bilgiyi üretmek üzere verilerin incelenmesini ve yorumlanmasını gerektirir (Bowen, 2009: 27). Doküman analizi ile ders kitaplarından toplanan verilerin çözümlenmesinde ise içerik analizi tekniği kullanılmıştır. Yaygın olarak kullanılan ve nitel bir araştırma tekniği olan içerik analizi, metinlerden (ya da diğer anlamlı şeylerden) kullanıldıkları bağlamlara göre tekrarlanabilir ve geçerli çıkarımlar yapmaya yönelik bir araştırma tekniğidir (Krippendorff, 2004: 18). İçerik analizinde yapılan işlem, birbirine benzeyen verileri belirli kavramlar ve temalar çerçevesinde bir araya getirmek ve bunları okuyucunun anlayabileceği bir şekilde düzenleyerek yorumlamaktır (Yıldırım ve Şimşek, 2013: 259). Bu çalışmada ders kitaplarından toplanan veriler "biz kimiz?" ve "onlar kim?" temaları altında analiz edilmiştir. Çalışmanın verileri, güvenirliği sağlamak üzere iki alan uzmanı tarafından ayrı ayrı incelenerek analiz edilmiş ve nihai olarak elde edilen bulguların birbirleriyle tutarlı oldukları tespit edilmiştir.

\section{BULGULAR VE YORUMLAR}

\section{Biz Kimiz?}

Toplumun türü ne olursa olsun seçkinlerin yaptıkları ve yazdıkları, daima bir "biz" bilinci oluşturmak, bu bilinci güçlendirmek ve bunu da ulvi bir sadakat odağ 1 çerçevesinde gerçekleştirmek amacına dönüktür. Tabiidir ki bu odak, söz 


\section{I.D. Cam ve M.B. Yılar $\quad$ 100. Yıl Dönümünde Maraș Savunması...}

konusu toplumdaki hâkim sınıfın çıkarları gözetilecek şekilde belirlenir. Ataların ruhu, Tanrı ve hükümdar, esasen toplumların etrafında bütünleşmeleri arzulanan birer yüce sadakat odağını teşkil etmişlerdir. Bu durum, özellikle 18. yüzyılın sonlarında patlak veren Fransız Devrimi ile birlikte değişmiş ve yeni yüce sadakat odağ 1 "millet" olmuştur. Millet, insanların yeni "biz" duygusunu ifade etmekteydi (Oran, 1993: 44).

Farklı şekillerde tanımlanan millet, esasen milliyetçiliğin mütemmim cüzüdür. Hemen hemen bütün milliyetçi duygu, ideoloji ve hareketlerin dayandığı temel nokta millettir. Millet, milliyetçiliği ete kemiğe büründüren bir fonksiyonu yerine getirir. Neredeyse tüm siyasal, tarihsel ve kültürel açıklamalar millet temel alınarak yapılır. Zira milliyetçilik, ancak belirli bir milletle varlık kazanır ve o millet üzerine inşa edilir. Milletsiz bir milliyetçilik söz konusu değildir. Milliyetçilik, insanların benzerleriyle bütünleşmek suretiyle kendilerini güçlü, güvende ve erinç içerisinde hissetmek için tarih boyunca başvurdukları başlica yollardan biri olmuştur. Bir ulus-devletin resmî ideoloji, tarih, görüş ve kurumlarında resmî bir milliyetçilik anlayışının olması, keza sıklıkla tesadüf edilen bir durumdur. Böyle bir devletin eğitim kurumlarında söz konusu anlayışın benimsenmesi ve tekrar tekrar üretilmesi de bu bağlamda doğal karşılanabilir. Bunun yansımaları, hiç şüphesiz "biz" bilincinin inşasında ciddi bir önem atfedilen ders kitaplarında rahatlıkla tespit edilebilir. Nitekim kurulduğu zamandan bugüne değin bir ulus-devlet olarak Türkiye Cumhuriyeti'nin resmî ideolojisi ve tarih anlayışı doğrultusunda biçimlendirilen ders kitaplarının ana misyonu, "Türklük" temelli "biz" bilinci oluşturmak, bunu yaygın bir hale getirmek ve yeniden üretmek olmuştur (İnal, 2004: 245, 248-249; Oran, 1993: 43). Bu yaklaşım, günümüz ders kitaplarında belirgindir. Bunun kayda değer bir örneğini, özellikle Mondros Ateşkes Antlaşması sonrasında işgale uğrayan Maraş'ta yaşananlar ve bu süreçte yapılan savunmaya ilişkin satırlarda açıkça görmek mümkündür.

Öncelikle vurgulanmalıdır ki Maraş'ta yaşanan gelişmeler, özellikle Fransızların şehre girişlerinden sonra cereyan eden bir olayla başlatılmıştır. $\mathrm{Bu}$ olay, incelenen dört ders kitabının ikisinde "Türk" (Ataş \& Ataş, 2018: 75; Tüysüz, 2018: 53), birisinde "Türk" ve "Müslüman" (Çevik, Koç \& Şerbetçi, 2018: 77-78), bir ders kitabında ise sadece "Müslüman" (Baydar \& Öztürk, 2018: 78) olarak tanıtılan kadın(lar) $\mathrm{a}^{2}$ yönelik bir saldırı şeklinde takdim edilmiştir. Saldırı esnasında söz konusu kadın(lar)a hitaben söylendiği belirtilen "burası artık Türklerin değildir. Fransız ülkesinde/memleketinde peçe ile gezilmez!"

\footnotetext{
${ }^{2}$ İncelenen ders kitaplarında, saldırıya maruz kaldıkları belirtilen kadınların sayısı net değildir. Bazı ders kitaplarında bu konuda çoğul bir ifade kullanılırken, bazılarında sadece bir kadından bahsedilmiş̧ir. Ders kitaplarındaki bu durum, konuya ilişkin literatürde de mevcuttur. Bkz. Eyicil, 2005: 56; Kerr, 1973: 63; Ünalp, 2018: 215.
} 
(Ataş \& Ataş, 2018: 75; Çevik, Koç \& Şerbetçi, 2018: 77) ifadelerine yer verilmek suretiyle Fransızların Maraş'1 Fransızlaştırmak yahut sahiplenmek konusundaki köktenci tavırları ve esasen bir Türk şehrinde Türklere karşı benimsedikleri "ötekileştirici" yaklaşım gözler önüne serilmiştir.

"Biz" vurgusunun merkezinde bu çerçevede ağırlıklı olarak "Türk milleti" yer almıştır. Türkler, söz konusu saldırı ve akabinde yaşanan gelişmelere ilişkin satırlarda, "onlara" karşı "meşru müdafaa" hakkını kullanan taraf olarak konumlandırılmış ve böylece Maraş'ta verilen mücadele haklı bir zemine oturtulmuştur (Ataş \& Ataş, 2018: 75; Baydar \& Öztürk, 2018: 78; Çevik, Koç \& Şerbetçi, 2018: 77-78; Tüysüz, 2018: 52-53). Maraş Savunmas1 esnasında gerek şehrin dışında ve gerekse de şehir dâhilinde büyük bir mücadele örneği sergilemiş ve canlarını feda etmiş pek çok erkek vardır. Bunlara, kendilerine biçilmiş toplumsal cinsiyet rollerinin ötesine geçerek hiçbir korkuya mahal vermeden yaşanan çarpışmalara cesaretle atılmış yahut şehit düşen eşinin silahlarını kuşanarak korkusuzca savaşa katılmış kadınlar ile millî kuvvetlere yemek, su ve cephane taşımış, postacılık yapmış ve tren raylarını sökerek ya da köprü uçurarak düşmanın hareket kabiliyetini zayıflatmış çocuklar da eklenmelidir (Eyicil, 2005: 53-75; Kerr, 1973: 62-64, 67-71, 80-85, 93-102; Ünalp, 2018: 215-229). Oysa Maraş Savunması'nın bu erkek, kadın ve çocuk aktörleri ders kitaplarında genellikle "kuva-yı milliye birlikleri", "Maraşlılar/Maraş halkı" ve "Türkler/Türk milleti" gibi daha genel ifadelerle geçiştirilmiş; sadece Çakmakçı Sait, Sütçü İmam ve Rıdvan Hoca'dan bizzat bahsedilmekle yetinilmiştir.

$\mathrm{Bu}$ aktörlerden ilkinin saldırıya uğrayan kadın(lar)1 korumaya çalışırken hayatını kaybettiği belirtilmiş ve kendisi "şehit" sayılmıştır (Tüysüz, 2018: 53). $\mathrm{Bu}$ suretle vatan ve millet için ölmenin kutsiyetine ve yüceliğine gönderme yapılmıştır. Çünkü "şehitlik", kutsal addedilen bir şey uğrunda yapılan savaşta yaşanacak ölüme bir methiyedir ve ölümsüzlük vaat etmektedir. Bireyin ölümsüzlüğü, mensubu olduğu milletin ebediliğiyle doğrudan ilintilidir. Bu bağlamda "şehitler" bir milletin varlık kaynaklarıdır. Onların fedakârlıklarındaki tam itaat hali, milletin ebediyetini garanti altına alan başlıca bir etmen durumundadır (Aykaç, 2013:151,159-160). Çakmakçı Sait'in aksine, istisnasız bir şekilde incelenen bütün ders kitaplarının konusu olan aktör Sütçü İmam olmuştur. O, bahsi geçen saldırının hedefi olan kadın(lar)a Çakmakçı Sait'ten sonra yardım elini uzatarak saldırıyı gerçekleştiren(ler)e müdahalede bulunan kişidir. Onun bu hareketi, Resim 1'deki gibi temsili bir çizimle görünür kılınmış; hatta bu çizimin yer bulduğu ders kitabında çocuklar, kendilerine yöneltilen bazı sorularla "biz"i, "onlar"a karşı bir araya getiren ve yekvücut kılan duygu durumu veyahut inanç, "onlar"ın amaçları ve Maraş'ta elde edilen başarının sırrı üzerinde düşünmeye sevk edilmişlerdir (Baydar \& Öztürk, 2018: 78). 


\section{İ.D. Cam ve M.B. Yılar $\quad$ 100. Yıl Dönümünde Maraș Savunması...}

Resim 1. Sütçü İmam Olayını Anlatan Temsilî Çizim

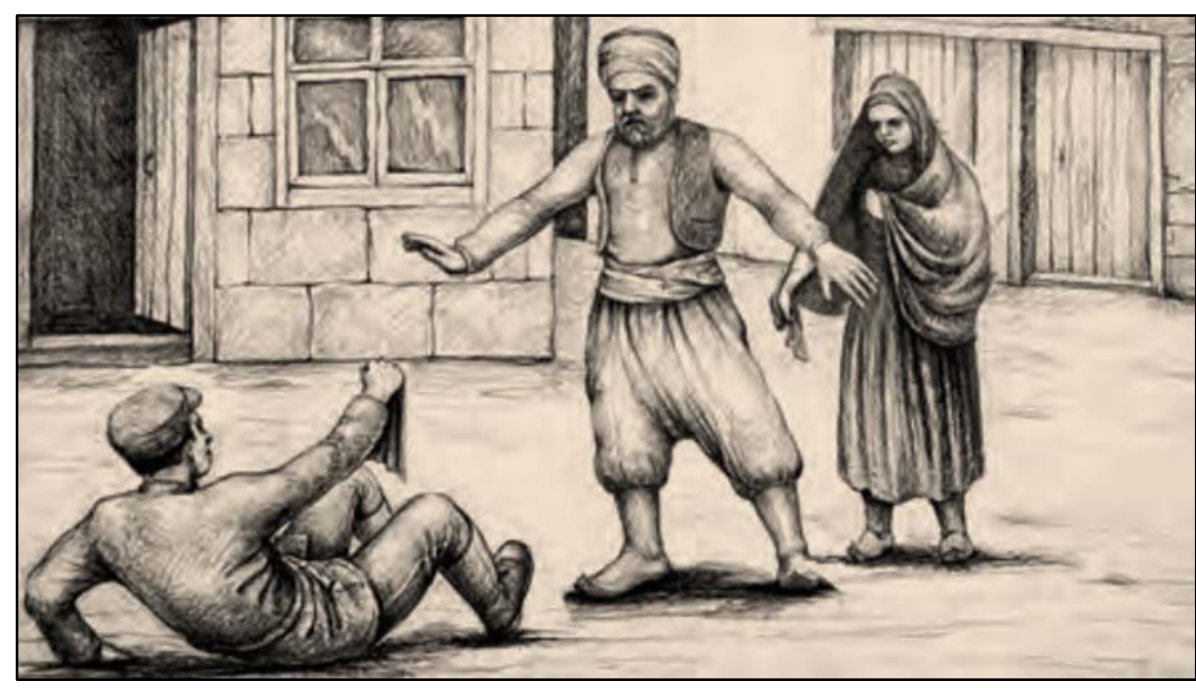

Kaynak: (Baydar \& Öztürk, 2018: 78)

Sütçü İmam millî bir kahraman, Maraş'ta "onlar"a ilk kurşunu atarak kurtuluş mücadelesini başlatan bir öncü, gündüzleri köy köy dolaşarak halk1 "onlar"a karşı direnişe çağıran, geceleri şehre inerek verilen mücadeleye yardımda bulunan ve şehrin kurtuluşuna katkı sağlayan bir vatansever (Tüysüz, 2018: 53) olarak resmedilmiştir. Kahramanlık ve vatanseverlik, bu anlamda "bizi biz yapan" değerler olarak öne çıkmıştır.

Ders kitaplarının Maraş Savunması'na ilişkin satırlarında bizzat anılan Rıdvan Hoca ise Fransız komutan Andre'nin talimatıyla Maraş Kalesi'ndeki Türk bayrağının indirilerek yerine Fransız bayrağının asılması üzerine cereyan etmiş olan bayrak olayının başaktörü olarak konumlandırılmıştır. Olayın aşağı yukarı benzer şekilde nakledildiği ders kitaplarında Ulu Cami imamı olduğu belirtilen Rıdvan Hoca, "kalelerinde hür bayrağı dalgalanmayan, esir bir memlekette cuma namazı kılınmaz" ifadelerini kullanarak bu durum karşısında hoşnutsuz olduğu kaydedilen halkı harekete geçiren, coşturan ve böylece Türk bayrağının yerine asılmasını sağlayan biri olarak kayda geçirilmiștir (Ataş \& Ataş, 2018: 75; Baydar \& Öztürk, 2018: 78; Çevik, Koç \& Şerbetçi, 2018: 77).

"Türk bayrağı" konusundaki bu hassas tavır, Resim-2'de görüldügü gibi temsilî bir çizimle görselleştirilmiş̧ir. Bu yaklaşımla yetişmekte olan nesillere bayrağın ne derecede önemli olduğu ve temsil ettiği değer daha açık bir şekilde 
anlatılmaya; bayrak gibi millî bir simge üzerinden milliyetçiliğin bir duygu, hareket ve ideoloji olarak zihinlerde somutlaşması (İnal, 2004: 248) sağlanmaya çalışılmıştır.

Resim 2. Bayrak Olayına Halkın Tepkisini Anlatan Temsilî Çizim

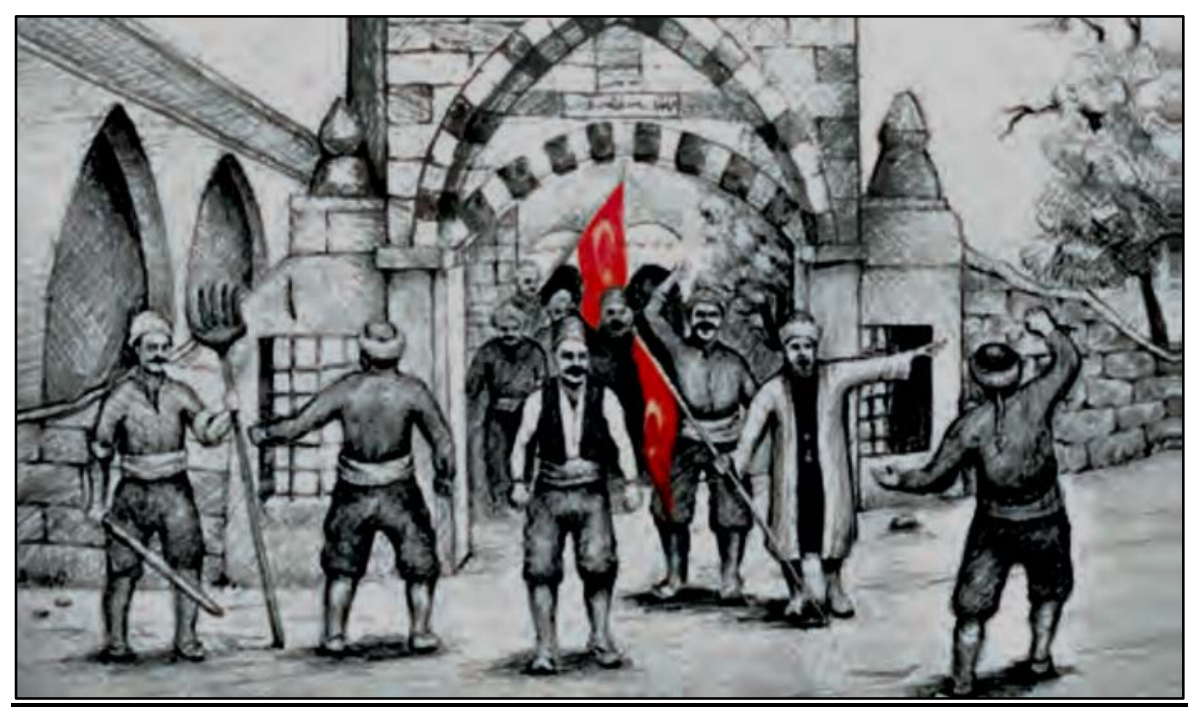

Kaynak: (Baydar \& Öztürk, 2018: 78)

Rıdvan Hoca'nın "özgürlüğ̈̈ olmayan bir milletin cuma namazı kılması doğru olamaz!" (Ataş \& Ataş, 2018: 75) ya da "hürriyeti elinden alınmış bir millet Cuma namazı kılamaz" (Baydar \& Öztürk, 2018: 78) biçiminde de ders kitaplarında yer bulan söz konusu ifadelerinde bayrağın bağımsızlığı simgelediği; bağımsızlı̆̆ın ise Türk milletinin olmazsa olmaz değerlerinin başında geldiği açık bir şekilde işaret edilmiştir. Türk bayrağının yerine Fransız bayrağının asılması bu bağlamda bağımsızlığın yitirilmesi ya da esaret altına girmekle eş değer görülmüş; böyle bir atmosfer altında mensubu olunan dinin gereklerini ifa etmenin doğru/mümkün olmadığı anlatılarak Türk bayrağına her halükârda sahip çıkmak, ona sayg1 ve bağlılık göstermek gerektiği mesajı verilmiştir.

\section{Onlar Kim?}

Milliyetçiliği temel alarak bir bilinç aşılamanın ilk başvuru basamaklarından biri millet iken; bir diğer basamak milletin kurulması arifesinde yüzleşilen daha ziyade savaş, dış saldırı, işgal vb. birtakım gelişmelerin özellikle ulus-devlet kurucularının zihin dünyalarında yarattı̆̆ "onlar" ya da "öteki" imgesidir. "Onlar"a dayanarak ve çoğu kez "onlar" temel alınarak yapılan tanımlamalar ve 


\section{I.D. Cam ve M.B. Yılar 100. Yıl Dönümünde Maraș Savunması...}

çizilen resimler, ulusal bütünleşme gibi hedeflerin gündemdeki yerlerini almalarını sağlarlar (İnal, 2004:305).

Ulus kurmak gibi temel bir misyonu olduğu belirtilen milliyetçi ideolojilerin kitleleri, prensipte milleti mobilize ettiği zaman dilimlerinde "biz"i tanımlamak, onu oluşturan unsurları birlik, beraberlik ve dayanışma ruhuyla daima yekvücut bir halde tutmak için "onlar", etkili bir kaynak olarak kullanılırlar. Kimliğini bulmak, tanımlamak ve nihai olarak korumak için yoksa bile icat edilmesi yoluna gidilen "onlar", bir yönüyle "biz"im varlığımızın yeniden, ancak daha önce mevcut olandan farklı bir şekilde tanımlanmasına imkân verir. Bu da "onlar"ın daha ziyade dışlanmaları, aşağılanmaları, yok sayılmaları, kötülenmeleri veya baştanbaşa olumsuzluk yüklü sıfatların/ifadelerin hedefi haline getirilmeleriyle mümkün olmaktadır. Zira mevcut problemlerin merkezinde "onlar"ın bulunduğu hususu, üzerinde mutabakat sağlanacak kadar sağlam bir zemin bulur. $\mathrm{Bu}$ çerçevede "onlar"ın milliyetçi ideolojilerde daha ziyade olumsuzlukları simgeledikleri söylenebilir. Bu durum, bütün milliyetçi ideolojiler gibi Türk milliyetçiliği için de geçerlidir. Nitekim bu ideolojide "biz" Türklük temelinde çeşitli değerler gündeme getirilmek suretiyle övülüp yüceltilirken, "onlar"a da kayda değer göndermelerde bulunulmuştur. Bunu, özellikle çeşitli kriz anlarına veya savaş gibi büyük ve olağanüstü durumlara dair metinlerde rahatlikla tespit etmek olanaklıdır (Güvenç, 1995: 7; İnal, 2004:305-307; Oran, 1993: 43).

Ders kitapları bu anlamda önemli ve dikkat çekici verileri barındırmaktadırlar. Cumhuriyet'in ilk yıllarından, bazı ara zaman dilimleri bir yana, yakın tarihlere değin "onlar"a ve eylemlerine ilişkin olmak üzere "katliamlarda bulunmak", "katliama girişmek", "Türk köylerini vahşiyane katliamlara uğratmak", "Türk zabitlerini şehit ederek ortalı̆̆ kana boyamak", "yapmadık vahşilik bırakmamak", "yağma etmek", "alçakçasına öldürmek", "kundaktaki çocuklara kadar Türk adını taşıyan her ferdin kanını içmekten zevk duyan namussuz ve vicdansız düşman", "alçak düşman", "adî bir mahlûk", "sürü" (Safran \& Ata, 1996) ${ }^{3}$ gibi aşırı sert, katı ve pejoratif değerlendirmeler yapılmıştır.

"Onlar"a yönelik bu toptancı, aşağılayıcı ve suçlayıcı yaklaşım şekli, günümüze doğru tedrici olarak yumuşamaya başlamıştır. $\mathrm{Bu}$ değişimde, Cooperation Intellectuelle ve devamı niteliğindeki UNESCO'nun milletlerarası bir uzlaşı ve anlayış ruhu inşa etmek üzere tarih ders kitaplarının yeniden gözden geçirilmesi konusunu gündeme getirmesinin, bu yöndeki önerilerinin, görüşlerinin ve çalışmalarının, başka ülkelerin olduğu gibi Türkiye'nin de bu konudaki yaklaşımının ve gerçekleştirdiği faaliyetlerin (Safran \& Ata, 1996; Şimşek \& Alaslan, 2014) etkili olduğunu belirtmek gerekir. "Onlar"a bakışta ve bu bağlamda yapılan değerlendirmelerde görülen bu değişimin, çok ileri bir

\footnotetext{
3 Bu konuda benzer ve karşılaştırmalı bir analiz için ayrıca bkz. Millas, 1989: 34-47.
} 
düzeyde olmasa da bazı küçük yansımaları incelenen ders kitaplarının Maraş Savunması ile ilgili satırlarında tespit edilebilir.

Bu satırlarda "onlar kim?" sorusunun cevabı Maraş'ın işgalinde rol oynayan İnilizler, Fransızlar ve Ermeniler olmuştur. Şehri ilk olarak işgal edenler anlatılırken "Ingilizler" gibi genel sayılabilecek bir ifade tercih edilmiştir. Şehrin "işgal edilmesi" eylemi dışında "Ingilizler"i olumsuzlayan veyahut kötüleyen herhangi bir sıfata/ifadeye yer verilmemiştir (Ataş \& Ataş, 2018: 74; Baydar \& Öztürk, 2018: 78; Tüysüz, 2018: 52).

Fransızlar ve Ermeniler ise "işgal etmek" dişında "saldırmak", "bölgede yaşayan Türklere saldırgan ve onur kirıcı davranışlarda bulunmak", "Türk kadınlarının yolunu kesmek", "halkın protestolarına ateşle karşıllk vermek", "halka daha sert davranmak", "taşkınlık yapmak", "taşkınlıklarını arttırmak", "intikam duygularıyla saldırıya geçmek" gibi birtakım olumsuz eylemlerin özneleri olarak konumlandırılmış; "işgal eden", "işgalci", "düşman" ve "eşkyya" (Ataş \& Ataş, 2018: 74-75; Baydar \& Öztürk, 2018: 78; Çevik, Koç \& Şerbetçi, 2018: 77-78; Tüysüz, 2018: 52-53) gibi sıfatlar kullanılarak tanımlanmışlardır.

Bahsi geçen eylemlerin özneleri ve söz konusu sıfatların hedefi hiç şüphesiz bütün Fransızlar ve Ermeniler değildir. İncelenen kitaplarda zaman zaman "Fransızlar" ve "Ermeniler" gibi ifadelere tek başlarına yer verilmek suretiyle kısmen de olsa genelleyici bir yaklaşım sergilenmiştir. Fakat bu kitaplarda "silahlandirllan Ermeniler", "Fransiz-Ermeni askerleri", "Fransiz birlikleri", "bazı Fransız askerleri", "bazı kişileri yaralayan Fransızlar", "olayı başlatan Fransız askeri", "Maraş'ı işgal için gelen Fransız askerleri", "işgalci Fransız kuvvetleri", "Suriye'den getirtilen Ermeniler", "taşkınlık yapmaya başlayan bir grup Ermeni", "Ermeni eşklyalardan biri", "Misır ve Suriye'den getirtilen Ermeniler", "Fransızların ordularına alarak silahlandirdikları bu Ermeniler", "Ermeni azınlı̆̆g" (Ataş \& Ataş, 2018: 74-75; Baydar \& Öztürk, 2018: 78; Çevik, Koç \& Şerbetçi, 2018: 77-78; Tüysüz, 2018: 52-53) gibi özellikle sorunların kaynağ sayılan belirli grupları işaret eden ifadeler daha ziyade tercih edilerek bahsi geçen milletleri bütünüyle hedef alan, toptan ötekileştirici bir yaklaşımdan kaçınılmaya çalışıldığı ifade edilmelidir.

\section{SONUÇ}

Bağımsızlık savaşları, hemen her milletin tarihinde özellikle başköşede yer bulan ve yetişmekte olan nesillere temel övünç kaynaklarından biri olarak anlatılan önemli gelişmelerdir. Millî Mücadele, bu noktada özellikle anılması gereken bu gelişmelerin başında gelmektedir. Pek çok millete örnek teşkil etmiş olan Millî Mücadele, bu bağlamda sadece Türk tarihinde değil; dünya tarihinde dahi kayda değer bir yere haizdir. Böylesine önemli bir mücadelenin her bir cephesi bu anlamda yakın bir ilgiyi sonuna kadar hak etmektedir. 


\section{I.D. Cam ve M.B. Yılar $\quad$ 100. Yıl Dönümünde Maraș Savunması...}

Anadolu'nun batısı ve doğusu bir yana, güneyi ve güneydoğusu büyük bir cephe olarak destansı bir mücadeleye sahne olmuş; Adana, Urfa ve Antep şehirlerinin dışında Maraş'ta vatan ve millet uğrunda can vermeye kadar varan fedakârlıklarda bulunulmuştur. Maraş Savunması, diğerleri gibi Millî Mücadele tarihinde bir dönüm noktası olmuştur. Pek çok bilimsel araştırmanın yakından odaklandığı ve farklı yönleriyle irdelediği Maraş Savunması, Millî Eğitim Bakanlığı'na bağlı okullarda okutulan ders kitaplarının da başlıca konularından birini teşkil etmiştir. Bu sayede çocuklar/gençler, konuya ilişkin satırlarda "biz"e ve "onlar"a dair önemli noktaları öğrenme fırsatı bulmuşlardır.

Bu satırlarda Türklügün baskın olarak merkezde yer aldığı bir "biz" bilinci inşa edilmeye çalışılmıştır. "Biz", genellikle iyi ve olumlu bazı değerlere temas edilmek suretiyle övülmüş ve yüceltilmiştir. Değerler, esasen bir milletin kimliğini oluşturan temel karakteristiklere karşıllk gelirler ve çeşitlidirler. Ders kitaplarının Maraş Savunması'na ilişkin satırlarında öne çıkan ve Türk milletine atfedilen değerler; aralarında birlik, beraberlik ve dayanışma hislerinin güçlenmesine imkân veren ve onların bu hislerle yekvücut bir şekilde yaşamalarına kaynaklık eden kahramanlık, vatanseverlik ve bağımsızlık olmuştur.

Bir millet içerisinde genel olarak kabul gören millî değerler dizgesinden ve bazı savunma reflekslerinden kaynaklanan dirençlere karşın, "biz"le ilişkili olmak üzere "onlar"a yahut "öteki"ye olan bakışta geçmişe nazaran günümüzde bir değişim yaşanmaya başladığı söylenebilir. Öyle ki ders kitaplarının Maraş Savunması özelinde sunduğu bulgular, "onlar"a ilişkin olarak geçmişte mevcut olan küçümseyici, aşağılayıcı, kötüleyici ve dışlayıcı bakış açısının yerini tamamen olmasa da belirli bir ölçüde nesnel bir yaklaşıma terk etmeye başladığını göstermiştir.

Ders kitaplarının ilgili kısmında yer yer bazı genelleyici ifadeler bulunsa da bütün bir milleti toptan ötekileştirici bir yaklaşımdan kaçınılmaya çalışıldığı özellikle vurgulanmalıdır. Bu da hiç şüphesiz hissi aşırılıkların yerine artık aklı, gerçekliği ve elbette barışı temel alan bir tarih anlayışının önemli bir göstergesi olarak okunmalıdir.

\section{KAYNAKÇA}

Akbıyık, Yaşar (1999), Millî Mücadelede Güney Cephesi (Maraş), AKDTYKAtatürk Araştırma Merkezi Yayını, Ankara.

Aykaç, Şafak (2013), "Şehitlik ve Türkiye'de Militarizmin Yeniden Üretimi: 1990-1999", Erkek Millet-Asker Millet: Türkiye'de Militarizm, Milliyetçilik, Erkek(lik)ler, (Der. N. Yeşim Sünbüloğlu), İletişim Yayınları, İstanbul. 
Bauman, Zygmunt (2010), Sosyolojik Düşünmek, (7. Baskı), (Çev. Abdullah Yılmaz), Ayrıntı Yayınları, İstanbul.

Bilgin, Nuri (2013),Tarih ve Kolektif Bellek, Bağlam Yayıncılık, İstanbul.

Bowen, Glenn A. (2009), "Document Analysis as a Qualitative Research Method", Qualitative Research Journal, Vol.9, No:2, pp.27-40.

Çabuk, Mustafa (2018), "Amerika Birleşik Devletleri Gazetelerinde Maraş Savunması", GÜ-Sosyal Bilimler Dergisi, C.17, S.1, ss.362-370.

Çayır, Kenan (2014), "Biz" Kimiz? Ders Kitaplarında Kimlik, Yurttaşıı, Haklar: Ders Kitaplarında İnsan Hakları III Projesi-Tarama Sonuçları, Tarih Vakfi Yayınları, İstanbul.

Dragonas, Thalia (2015), "Tehdit Altındaki Milli Kimlikle Başa Çıkmak", Tarih Eğitimi ve Tarihte "Öteki" Sorunu: 2. Uluslararası Tarih Kongresi Tebliğler, (2. Baskı), (Yay. Haz. A. Berktay \& H. Can Tuncer), ss.113124, Tarih Vakfi Yurt Yayınları, İstanbul.

Eyicil, Ahmet (2005), "Maraş Savunması", Atatürk Araştırma Merkezi Dergisi, C.XXI, S.61, ss.47-75.

Gönen, Cengiz (2005), Ulusal Kurtuluş Savaşının İlk Kahramanı Maraş, Lazer Yayınları, Ankara.

Gutek, Gerald L. (2014), Eğitime Felsefi ve İdeolojik Yaklaşımlar, Ütopya Yayınevi, Ankara.

Güvenç, Bozkurt (1995), Türk Kimliği: Kültür Tarihinin Kaynakları, (3. Baskı), Remzi Kitabevi, İstanbul.

İnal, Kemal (2004), Eğitim ve İktidar: Türkiye'de Ders Kitaplarında Demokratik ve Milliyetçi Değerler, Ütopya Yayınevi, Ankara.

Kerr, Stanley E. (1973), The Lions of Marash: Personal Experiences with American Near East Relief, 1919-1922, State University of New York Press, Albany.

Krippendorff, Klaus (2004), Content Analysis: An Introduction to Its Methodology, (2 ${ }^{\text {nd }}$ Edition), Sage Publications, California.

Manning, M. Lee ve Baruth, Leroy G. (2004), Multicultural Education of Children and Adolescents, $\left(4^{\text {th }}\right.$ Edition $)$, Allyn \& Bacon, USA. 
Millas, Herkül (1989), Türk-Yunan İlişkilerine Bir Önsöz: Tencere Dibin Kara..., Amaç Yayıncılık, İstanbul.

Oran, Baskın (1993), "Milliyetçilik Nedir, Ne Değildir, Nasıl İncelenir?", Birikim, S.45/46, ss.43-48.

Parlak, İsmet (2005), Kemalist İdeoloji'de Eğitim: Erken Cumhuriyet Dönemi Tarih ve Yurt Bilgisi Ders Kitapları Üzerine Bir İnceleme, Turhan Kitabevi Yayınları, Ankara.

Pingel, Falk (2004), Tarihi Öğrenmek ve Öğretmek: Ders Kitaplarını Araştırma ve Düzeltme Rehberi-Unesco, (2. Baskı), (Çev. N. Elhüseyni), Türkiye Ekonomik ve Toplumsal Tarih Vakfı Yayınları, İstanbul.

Safran, Mustafa \& Ata, Bahri (1996), "Barışçı Tarih Öğretimi Üzerine Çalışmalar: Türkiye'de Tarih Ders Kitaplarında Yunanlılara İlişkin Kullanılan Dil ve Yunanlılara İliş̧kin Öğrenci Görüşleri", Gazi Üniversitesi Eğitim Fakültesi Dergisi, No.1, pp.11-26.

Schmid, Wilhelm (2017), Düşmanlığın Faydaları, (Çev. Tanıl Bora), İletişim Yayınları, İstanbul.

Schnapper, Dominique (2005), Sosyoloji Düşüncesinin Özünde Öteki İle İliş ki, (Çev. A. Sönmezay), İstanbul Bilgi Üniversitesi Yayınları, İstanbul.

Şavkılı, Cengiz (2017), "Maraş'ın Kurtuluş Bayramı Kutlamaları ve Basına Yansımaları (1920-1950)", AÜ-Türk İnkılâp Tarihi Enstitüsü Atatürk Yolu Dergisi, C.16, S.61, ss.309-340.

Şimşek, Ahmet ve Alaslan, Funda (2014), "Milliyetçi Tarihten Milli Tarihe, Çatışmacı Eğitimden Barışçı Eğitime Doğru Türkiye'de Tarih Ders Kitapları", Akademik Bakış Dergisi, No.40.

Tekeli, İlhan (2015), "Tarih Yazıcılı̆ğ ve Öteki Kavramı Üzerine Düşünceler", Tarih Eğitimi ve Tarihte "Öteki" Sorunu: 2. Uluslararası Tarih Kongresi Tebliğler, (2. Baskı), (Yay. Haz. A. Berktay ve H. Can Tuncer), ss.1-6, Tarih Vakf1 Yurt Yayınları, İstanbul.

Ünalp, F. Rezzan (2018), "Birinci Dünya Harbi Sonunda Maraş'ın İtilaf Devletlerince İşgali ve Maraş Savunması", Gazi Akademik Bakış Dergisi, C.11, S.22, ss.205-235. 
Van Dijk, Teun (2015), "Söylem ve İdeoloji: Çokalanlı Bir Yaklaşım", Söylem ve İdeoloji, (Genişletilmiş 2. Baski), (Haz. B. Çoban ve Z. Özarslan), ss.15-100, Su Yayınevi, İstanbul.

Yakar, İbrahim Halil (2018), "Antep Savunması Ana Kaynaklarında Maraş", GÜ-Ayıntab Araştırmaları Dergisi, C.1, S.1, ss.49-62.

Yetişgin, Mehmet (2004), "Ermenilerin Maraş'tan Ayrılmaları, 1920-1922", Atatürk Araştırma Merkezi Dergisi, C.XX, S.58, ss.65-81.

Yıldırım, Ali ve Şimşek, Hasan (2013), Sosyal Bilimlerde Nitel Araştırma Yöntemleri, (9. Baskı), Seçkin Yayıncılık, Ankara. 